UNIVERSITY OF CHITRAL JOURNAL OF LINGUISTICS AND LITERATURE

VOL. 5 | ISSUE I | JAN - JUNE | 2021

ISSN (E): 2663-1512, ISSN (P): 2617-3611

\title{
Journey from Trauma to Transcendence Through Art Therapy: The Study of Laurie Halse
} Anderson's Speak

Amman Shoaib

Visiting Lecturer, Department of English, University of Central Punjab, Lahore, Pakistan amman.shoaib@ucp.edu.pk

Usama Javed Iqbal

Visiting Lecturer, Department of English, University of Central Punjab, Lahore, Pakistan usama.javed@ucp.edu.pk

\section{Abeera Shaukat \\ Associate Lecturer, University of Narowal, Narowal, Pakistan \\ abeera.saqib@uon.edu.pk}

\begin{abstract}
The aim of this research paper is to analyze the novel of American writer, Laurie Halse Anderson, entitled Speak, through the lens of art therapy to highlight that the journey from trauma to transcendence is possible through the therapeutic medium of art. This study examines all the traumatic encounters which the protagonist of Speak, Melinda Sordino, must face in her adolescence period and her constant struggle to cope with those experiences. The research substantiates that Anderson's novel frames speech and recovery from depression and traumatic stress possible through the artistic renderings. Theoretical framework of this paper is encapsulated in Shaun McNiff's theory of art as medicine. The scopes of existing studies of Laurie Anderson's Speak are limited to the exploration of the impact of traumatic encounters on the psychological and social growth of the young adult but this has not been clarified that how the protagonist overpowers the weaknesses and frailties of her mind through the healing properties of art. The decipherment of the element of art therapy in Speak fills the gap in research on trauma recovery through expressive art in Young Adult literature. Thus, the findings generated from this study might help the future researchers in exploring various dimensions of Young Adult Literature to study the implications of trauma recovery through creative art therapy.
\end{abstract}

Keywords: trauma, sexual harassment, transcendence, art therapy, young adult literature

\section{Introduction}

In this world, human beings must encounter different experiences in their lives. Sometimes, those experiences educate them, make them more strong, mature, and courageous, and they give 


\section{UNIVERSITY OF CHITRAL JOURNAL OF LINGUISTICS AND LITERATURE VOL. 5 | ISSUE I | JAN - JUNE | 2021

them a sense of security as well. Sometimes, the excruciating experiences which human beings face exert negative and harsh footmarks in the memory of people and force them to question their very own existence. In this game of life that is filled with emotional complications, most people experience psychosomatic stress besides psychological disorder that disturbs them and makes them feel agitated and perturbed. This state of agitation and disturbance, where one's inner self is left in turmoil, often reports the feelings that are federated with trauma. In The Diagnostic and Statistical Manual of Mental Disorders, the American Psychiatric Association defines trauma as a mentally troubling occasion that is outside the "range of human experience" (2015, p. 19). Trauma shakes the nervous system of victims; it leaves them into a psychologically disordered and dysfunctional situation. Brain areas implicated in the stress response include the amygdala, hippocampus, and prefrontal cortex and traumatic stress can be associated with "lasting changes in these three areas" (Bremner, 2006, p.453). Although, these three parts of the brain keep on growing with the passage of time, the effects of trauma can affect the developmental process and show long term dysregulation of these parts of the human brain. During a traumatic experience, the nervous system of the brain surely "increases the stress hormones" and "decreases the positive sensibility" of human beings (2006, p. 461). The elevation and aggrandizement of stress hormones do not allow the body to work or regulate properly. It leaves ineffective traces on the mental or psychological growth of the sufferer and affects the physical and biological makeup of man's anatomy.

It is very difficult for trauma victims to heal their psychological wounds and emotional scars. They cannot easily spit their anger out even if they want to because it is considered that traumatic memories remain "intact" and can be experienced with the same intensity as when the event occurred and the "imposition of traumatic memories upon a victim is immense" (qtd. in Riggs, 2010, p. 21). Psychological and emotional scars like physical wounds cannot be forced to heal quickly. Although, it is very difficult for the people, who encounter traumatic events, to cope with their trauma, this is not impossible for them because the human psyche has always an immense capacity for recovery. The impacts that appear disastrous and representative of constant damage on the brain can be reversed too. Amygdala, hippocampus, and prefrontal cortex can be badly affected by any traumatic incident, but these areas of brain can again learn to remain relax and 


\section{UNIVERSITY OF CHITRAL JOURNAL OF LINGUISTICS AND LITERATURE VOL. 5 | ISSUE I | JAN - JUNE | 2021

calm. This presents that recovery from trauma is not impossible, victims can overcome their traumatic stress. Some people believe that healing from trauma is not possible. Primo Levi, who himself is the survivor of trauma, mentions that the "injury cannot be healed... it extends through time" (1986, p.64). But this is an accepted fact that trauma victims can heal their psychological plus emotional wounds as there are "many paths that offer a blueprint for emotional recovery" (Heller, 2015, p.32). Trauma victims can recover while indulging themselves in different positive and creative activities like drawing, painting, writing, and music. Telling the narrative of trauma is considered a dominant paradigm in the recovery of trauma. While expressing their suppressed emotions, the victims can spit their anger out which helps them in finding peace and sanctuary from trauma, depression, and anxiety.

In this modern scientific world, there are different types of therapies to help the trauma victims in coming out of their anxiety and pressure. The therapies that are most often used for trauma are psychodynamic therapy, cognitive behavioral therapy, dance therapy, music therapy, art therapy, massage therapy, martial arts therapy, adjunctive therapy. However, art therapy is considered one of the best treatments to heal the suffering soul from stress and pressure. People who experience trauma can transform their altered lives through participating in art-making, artwork, or through creative engagements. Some objectives of art therapy are to actuate emotions, rebuild trust, and reduce a feeling of "isolation and separation" (Wertheim-cahen, Dijk, and Drozdek, 2004, p. 426). People often retreat into silence after encountering traumatic events, but they can convey their messages through their art. They can also express their suppressed emotions through their art projects. The victims do not need to be very artistic or creatively talented to take part in art therapy, people who do not know anything about art can even participate in this type of therapy while drawing or painting whatever they want to explore through colors and brushes. The process of art-making can be called the process of recovery and discovery. It makes people contemplate, meditate and think about their own selves and because of this meditation, victims can bring positive changes in their lives while expressing themselves in their projects.

Speak, 1999, is written by a famed American writer, Laurie Halse Anderson, in a diary format as the protagonist narrates her story from her own point of view. The story is about a girl 


\section{UNIVERSITY OF CHITRAL JOURNAL OF LINGUISTICS AND LITERATURE VOL. 5 | ISSUE I | JAN - JUNE | 2021

who encounters various traumatic incidents in her teenage life. All the incidents leave a grating and strident impact on the psychological growth of the protagonist and turn her into a victim of depression and trauma. Later, she learns to express her suppressed emotions into her art projects in art class and heals her traumatic stress.

\section{Significance of Study}

The scopes of the existing studies of this novel, Speak, are limited to the exploration of the negative and harmful impacts of traumatic encounters like rape and harassment on the growth of young adult, Melinda Sordino, but there is a gap in criticism regarding how young adult portrayed in this novel overpowers the weaknesses and frailties of her mind through the power of art therapy. By exploring the element of art therapy in Speak, the research intends to fill this gap in the literature. It offers room for further research on trauma recovery through art therapy in Young Adult fiction.

\section{Research Questions}

Following are the research questions which will be answered by this study:

What are the traumatic encounters experienced by the protagonist in Speak that push her to swirl into depression and trauma?

How does Anderson present art as a medium of transformation in her novel?

\section{Literature Review}

The primary text that is used in this paper is Laurie Halse Anderson's novel. Anderson is an American writer and an "author of four award winning novels" (Kristiana, 2012, p.13). The novels are Fever, Wild at Heart Series, Saudi, and Habla She has written many novels and her famous works are Speak, Shout, Chains, Catalyst, Twisted, Winter Girls, and Ashes. The main themes of Anderson's works are isolation, violence, sadness, and friendship. But in almost all her works, Laurie Halse Anderson mainly focuses on teenagers and children. In her novels, the author has presented the hard life of teenagers by showing their problems and dilemmas. But she has also incorporated this idea in her books that teenagers can deal with their problems as well in different ways. Katrin Rahma Pandansari asserts that, Anderson has worked on creating the "awareness about sensitive issues in the society" while writing different literary works. She beautifully projects 


\section{UNIVERSITY OF CHITRAL JOURNAL OF LINGUISTICS AND LITERATURE VOL. 5 | ISSUE I | JAN - JUNE | 2021

the problem and then shows how to deal with those problems $(2014$, p. 61). Her focus is on the sexual assault of young adults and how they suffer because of these excruciating encounters.

The research "A Study of Depression and Healing as Reflected in Anderson's Speak" conducted by Novia Harry Rustiani explores the symptoms of stress and depression which Melinda, the main protagonist of the novel, suffers because of her rape. The researcher purports Beck's cognitive theory of depression to reveal the process of depression suffered by Melinda. While analyzing the idea of depression in Speak, the researcher presents Melinda as a victim instead of presenting her as a survivor. She concludes that Melinda is suffered from 23 symptoms of depression.

Melani Nurfita Arifin's “The Girl's Infliction Caused by Rape as Reflected in Laurie Halse Anderson's Speak" focuses on the traumatic experience which Melinda faces because of being rape victim and change of her attitude that is specifically caused by the excruciating encounters in her life. The writer has used the Post-Traumatic Stress Disorder by Merril D. Smith as a theoretical framework for this paper in order to analyse the issue. The paper presents that because of the rape, the protagonist of this novel, Melinda Sordino, has a "mental suffering that is reflected in her daily attitudes" (Arifin, 2018, p.16). Another researcher Marybeth Ragsdale-Richards deals with Laurie Halse Anderson's Speak as a pseudo-feminist text. In her essay "Caught Between Voices, Caught Between Pages: Considering Laurie Halse Anderson's Speak as a Pseudo-Feminist Text," Richards argues that this text allows the readers to "uncover the knowledge about the violence Melinda experiences" and she also talks about the portrayal of lack of female empowerment in the novel. The author of this essay illustrates that Speak does not only seek to disrupt the culture of rape, but it also reinstates a "hyper patriarchal worldview" (Richards, 2019, p.4).

In her article "Coping behaviour of Melinda in Speak by Laurie Halse Anderson: An Individual Psychological Approach," Kristiana reveals the coping behaviour of Melinda reflected in Anderson's Speak. Kristiana figures out that the character of Melinda gets "maturity in her personality" that is shaped from her efforts to cope her problems in gaining her life goals. Anderson's Speak gives a message that the girls should speak up for themselves and raise their voices for what they believe in "or nothing will ever change" (2012, p.11). "The Cause and Effect 


\section{UNIVERSITY OF CHITRAL JOURNAL OF LINGUISTICS AND LITERATURE VOL. 5 | ISSUE I | JAN - JUNE | 2021

in Melinda's Traumatic Experiences: A Psychosocial Analysis in Speak" by Katrin Rahma explores the impact of sexual harassment on Melinda's psychological condition. This study identifies how traumatic experiences in Melinda's life affect her psychosocial development. To answer these objectives, the researcher used the psychosocial development theory by Erikson. The objectives of this research paper are somewhat like to the objectives of Novia Harry's research. Because the focus of both researchers is on the impacts of sexual harassment and to explore the mental condition of Melinda. Like Rustiani, Rahma also comments that Melinda shows her development through her artwork and creativity and art seems to be the thing that draws her back to normal life. In both the papers, the focus of researchers is not on the notion of art therapy. Novia Harry had applied the cognitive theory of Beck whereas Katrin Rahma applied Erikson's theory of Psychoanalysis.

Various research has been conducted from different perspectives on this novel. This research also uses the same novel of Laurie Halse Anderson but the focus in this research is on exploring the significant role of art as therapy for psychological trauma in Speak. In this paper, the focus is on how art helps victim of rape and sexual assault to come out of the depression and stress in Speak while utilizing Shaun McNiff's theory of Art as Medicine. This current research may be amongst the first to explore this idea of art therapy in the novel of Young Adult Literature.

\section{Research Methodology}

This research entails a content-based, textual analysis of Laurie Halse Anderson's Speak as the primary text. The applied theoretical framework is Shaun McNiff's art theory called Art Therapy. The reviews pertaining to the aforementioned author, novel and theory form the secondary sources of this paper. Both, print and electronic media have been utilized as a secondary source. Art as Medicine and Art Heals have also been consulted as a part of the secondary source for this research. It is qualitative research and is exploratory and inductive in nature. The method employed for this research is wholly subjective and holistic. The descriptive method is used in gathering the required and needed information for this study. The technique through which this data is collected is by making a study of the novel carefully to have comprehensive perception of the novel. Some notes have also been taken to highlight the material related to this research. 
UNIVERSITY OF CHITRAL JOURNAL OF LINGUISTICS AND LITERATURE VOL. 5 | ISSUE I | JAN - JUNE | 2021

Labelling and classification of the data is also done that is relevant to this current study. To make the conclusion of this research, the data is carefully inspected according to the content along with theory, that is utilized in this research paper.

\section{Discussion}

The research intends to focus on the idea of art as a healing power through the creation of drawings and paintings and the aim of this study is to show how Anderson's novel Speak frames speech and recovery from post-traumatic stress disorder as possible through the therapeutic properties of creative art. Shaun McNiff's idea of art as medicine is utilized as a theoretical framework in this paper.

Shaun McNiff's theory of art as medicine clearly demonstrate the idea that the therapy of imagination and soul is within the reach through expressive art like drawing and painting. In Art as Medicine, McNiff proposes that when an artist creates or paints an image, it becomes an order through which "the creative mind treats itself, heals itself and then reuses its vigorous energy back to the daily living" $(1992$, p.36). He further contends that the artistic images appear in the mind of depressed, isolated, and distraught soul and the artist can heal from his psychic illness while creating those images on the paper with the help of different colors. In his book, McNiff presents mutuality between the depressing soul and creative art. If the patient paints from his soul while putting his inner emotions in the piece of art, that piece of art becomes "an angel of transformation" for him and pragmatically treats the psychological disease of that person (McNiff, 1992, p.41). He lays emphasis on the idea that art making is a medicine and this advances through various periods of formation and meditation. According to him, the medicine to the artist is proposed by the creation of art and then meditation on the image during the process of creation. During the process of drawing an image, the mind of the artist indulges itself in direct conversation with the image by putting its ego aside and through this concentration and reflection, transformation starts taking place in the suffering soul. By conversation with the image, McNiff means that the artist starts imagining stories about his artwork and what it portrays and starts concentrating on the past traumatic events. It cannot be assumed that some expressions heal, and others do not, "every aspect of art contributes to healing the psychological wounds" and each image gives special award to the 


\section{UNIVERSITY OF CHITRAL JOURNAL OF LINGUISTICS AND LITERATURE VOL. 5 | ISSUE I | JAN - JUNE | 2021

maker of its art (McNiff, 1992, p.42). The creativity can help people in recovering from trauma when the artist incorporates his conflicted and complex feelings to make the sense of his chaotic and disordered inner world as artwork turns into a custom demonstration that opens individuals to the "experience of soul" (1992, p.46). Creative art therapy incorporates psychotherapeutic procedures with the inventive technique to improve "mental health and wellbeing" (Cherry, 2018, p.38). Whereas the British Association of Art Therapists explains that the treatment through art is simply the utilization of art materials for "self-expression and reflection" in the presence of an art advisor, it enables change and development on personal level using art materials in a safe and "facilitating environment" (qtd. in Edwards, 2004, p.18). Those people who utilize the technique of art therapy, they surely use creative skills as an approach to get to their psyche and tap into their sentiments in a manner that can be troublesome with basic talk therapy.

Based on the aforementioned argument, this paper discusses Laurie Halse Anderson's novel, Speak. The main objective of this research is to trace all the excruciating encounters which the protagonist, Melinda Sordino, must face in her adolescence period and how she constantly struggles to cope with those traumatic experiences to survive in this world while using art as medicine for herself.

Melinda Sordino, the 14-year-old protagonist of Anderson's novel, experiences many traumatic events in the adolescent period of her life. This novel is written in a diary-format and all the crucial incidents which Melinda faces are exposed by the protagonist herself. The very first extremely painful experience which she must face in her teenage is her rape by a very close friend, Andy Evans, in the party. Shocked by this act, she calls cop but because of the guilt, shame, and embarrassment, Melinda speaks nothing in front of the police and keeps her mouth shut. This violent action makes her swirl into gloomy dejection and dark depression. Rape or sexual violence impacts every aspect of victim's life including physical, mental, and spiritual health. The protagonist of Speak also experiences many other excruciating encounters in her life because of her rape or sexual assault. It does not only leave negative impact on her mental, and physical condition but her social life is also badly impacted by this traumatic encounter. She starts remaining silent since she does not have the foggiest idea how to manage this aside from being 


\section{UNIVERSITY OF CHITRAL JOURNAL OF LINGUISTICS AND LITERATURE VOL. 5 | ISSUE I | JAN - JUNE | 2021

quiet. Melinda's friends leave her as they think that it is she who had spoiled the party while calling the cop without any reason as nobody knows that she was raped. Even the young girl who "suffered through Brownies" with her, who instructed her how to swim, who understood about her parents, who did not ridicule her room, has also become a "witch and a traitor" (Anderson, 1999, p.7). Her only friend in the school, Rachel, has left her because of her calling the cop and spoiling the party. One day, when Melinda encounters Rachel, the young lady mouths silently to Melinda that "I hate you," she simply turns her back to her and starts laughing with her friends and Melinda feels very sick at the heart due to her friend's extremely poor behavior (Anderson, 1999, p.22). This shows how Melinda is feeling because of her friend's harsh behavior. Andy Evans, the guy who had raped the protagonist, follows her, and makes her more scared while threatening that he would rape her again and kill her if will open her mouth. All the other friends of Melinda leave her, keep on criticizing her, and make fun of a weak and timid girl. Melinda does not only suffer the breakdown of her relationship with her friends but also with her parents. The relationship between her mother and father was already not on good terms as Melinda herself mentions that "I bet they'd be divorced by now if I'd not been born" $(1999,25)$. She keeps on telling the readers about her parents' fights on trivial matters. Her relationship with her parents is weak and she suffers from lack of communication with her parents after her rape. They do not even take steps to strengthen the bond with their daughter and therefore, Melinda feels quite lonely and isolated. The depressed soul illustrates painfully in the diary format novel that she communicates with her parents through "notes on the kitchen counter" when she needs supplies for the school or ride to the shopping center, whereas her parents only "leave notes about what time they will be back from work (1999, p. 43). Besides this, there was nothing else to communicate amongst them.

Melinda's attitude displays helplessness as well as hopelessness. She starts skipping her school and finds herself in an abandoned janitor's closet while hiding herself during the school time. She hides over there and sleeps whenever she feels anxious and depressed. Soon, the protagonist becomes an outcast everywhere. In fact, when all the students of ninth grade are "herded into the auditorium," it is Melinda who remains isolated, sits alone without any friend, and even laughed at by her schoolmates (Anderson, 1999, p.47). It is not wrong to say that Melinda 
UNIVERSITY OF CHITRAL JOURNAL OF LINGUISTICS AND LITERATURE VOL. 5 | ISSUE I | JAN - JUNE | 2021

does not only lose her relationships with others, but she also even loses herself in this difficult and complex race of life. She finds no way to come out of these harsh realities of life. Her transformation takes place from a very lively girl into a drastically disconnected teenager. After encountering every traumatic incident, Melinda feels that something is "cracking inside her" and her ribs are collapsing in her own lungs (1999, p.41).

The author of Speak, Laurie Halse Anderson, has used symbolism to portray the inner state of Melinda that is badly suffering from post-traumatic stress disorder. The most prevalent symbols in this novel are mirrors, lips and mouths, and closets. These symbols add very intense meanings to the text. Various accounts of lips and mouths in this novel underlines Melinda's inability to communicate others. Anderson highlights that Melinda keeps on biting her lower lip. Melinda's lips are presented as paralyzed, swollen, dry, and scabby. The protagonist herself describes her face as something very scary and ugly, she mentions that her eyes are "two muddy circles" under very thin eyebrows, her nose is "piggy," and her face looks like something "chewed up" (Anderson, 1999, p.47). Melinda Sordino once again uses very bitter imagery while presenting her nails. She shows that her nails are very rough that are chewed to the "bleeding point" and she has applied "BLACK DEATH nail polish" on them, which is obviously a very gloomy portrayal (1999, p.48). The grotesqueness and ugliness of her face, the disfigurement of her nails and black death nail polish on her ugly nails clearly represent the guilt, shame, gloominess, darkness, and ugliness Melinda's inner self is experiencing after facing all the harsh incidents. Because of these excruciating encounters, Melinda is even unable to face herself. She stops seeing herself in the mirror and puts down the mirror of her room. She experiences identity crisis and finds herself stuck in a limbo. Because of this frustration and inner turmoil, Melinda also once tries to commit suicide while clutching the pin of her clipboard $\mathrm{n}$ her wrist but fails to kill herself.

After confronting various unbearable events in her life, she luckily joins Mr. Freeman's art class in her new semester of Merryweather High School. In the very first art class, Mr. Freeman welcomes all his students while saying "welcome to the only class that will teach you how to survive. Welcome to art class...if you will not learn art now, you would never learn to breathe" (Anderson, 1999, p.53). Mr. Freeman connects art with life and tells his students that it is only 


\section{UNIVERSITY OF CHITRAL JOURNAL OF LINGUISTICS AND LITERATURE VOL. 5 | ISSUE I | JAN - JUNE | 2021

through art that they can express their bottled-up emotions in front of others. The art teacher tells his students that the art that is created without feelings and sentiments is "like a chocolate cake without sugar" (1999, p.56). This is what Melinda understands and then decides to free herself. In the beginning of the new year of the school, Mr. Freeman assigns a keyword to every student. The protagonist of this novel also plunges her hand into the bottom of the globe and fishes out her paper. The keyword that she finds on the paper is "tree". All the students including Melinda are instructed to focus on exploring the assigned keywords throughout the whole year. At the same time, the art teacher, Mr. Freeman, suggests Melinda to work on the trees without thinking about them. According to him, an artist should think about love, or hate, or joy, or rage, whatever makes him feel something (Anderson, 1999, p.56). Rather than thinking about the trees, Melinda starts concentrating on "what makes her palms sweat, her toes curl. She focuses on that feeling" (1999, p.57).

In the beginning, Melinda feels that this assignment is not only easy but interesting too, but later she realizes that this is not an easy task to explore inner sentiments and emotions. She begins painting the tree while focusing on her sentiments and the very first image which she produces is of dead tree. The tree is hit by lightning, thunderbolts, and thunderclaps. Without giving up, she paints more than 300 tree images, but all of them look like the trees that are caught by some forest fire or blight. The trees that Melinda draws consistently, and the trees she ponders in her brain, speak to how she feels about herself. The trees hit by lightning portray Melinda's psychological condition and inner state. Just like Melinda, her trees are also struck by outer and external force. The protagonist herself is frustrated and that's the reason that she cannot project the trees that are full of life. She feels that she is barely surviving in this world and represents herself by drawing dead and lifeless trees. She draws whatever she feels to lessen the burden from her shoulders. According to Shaun McNiff, when the depressed soul decides to put his suppressed emotions onto the paper, the negative images appear in the mind of that person as he tries to connect the implicit and explicit memories. While drawing those negative, dark, harsh, and bleak images, the victim heals himself (McNiff, 1992, p. 110). This happens with the protagonist of Speak as well. She does not only draw these dead trees in the beginning that represent her inner condition but she picks up 


\section{UNIVERSITY OF CHITRAL JOURNAL OF LINGUISTICS AND LITERATURE VOL. 5 | ISSUE I | JAN - JUNE | 2021

the Barbie doll and places tape on the mouth of doll and glues the bones together and "arranges them on a very dark piece of paper," and puts the "knives and forks" on the paper and glues them in a way that it looks as they are striking the bones on the dark paper (Anderson, 1999, p.59). This is a very grim depiction of how Melinda is feeling as knives and forks are attacking the bones. The tape she places on the mouth of Barbie doll illustrates how she is forced to remain silent about whatever she has confronted in her life. The attack of forks and knives on the bones represent the attack that was made by Andy Evans on Melinda's virginity. Melinda portrays her inner self through these negative projections. While doing this, she heals herself and releases her bottled-up emotions.

Frustrated soul of Melinda finally starts feeling that there has been some "progress" in her and there has been some "progress" in her whole tree project of art (Anderson, 1999, p.64). She feels that she has also gone through many different phases like Pablo Picasso due to the art work. Melinda accepts that all her earlier painted trees look like "they had been through a forest fire or blight" and by painting these images she feels much "better" (1999, p.66). This proves that the "negative and disturbing images are vital stimulants for healing in that toxin is the antitoxin" (McNiff, 1992, p. 117). After that, she draws a tree and surprisingly, the tree is not dead, it is not hit by lightning. Mr. Freeman comments that "this is not dead; this is an average tree. Breathe life into it (Anderson, 1999, p. 69). We see progress in Melinda's attitude and behavior through exhibiting these projections and disturbing images of trees. She realizes that she is getting better. She feels comfortable and good by portraying these dark and lifeless images. Melinda makes a new friend, David, and goes to market to buy her clothes. The girl who has never talked about her rape, she starts meditating in isolation that how could she speak up about that night when she was raped? She thinks "how can I talk to them about that night? How can I start" (1999, p. 70)? This is quite clear that she is still stuck, and she has not gained voice up till now, but she has started thinking about speaking whatever she has faced in her life all alone.

After creating the dead tree image for more than three hundred and fifteen times, and spoiling more than six linoleum blocks, Melinda starts seeing a very "strong and healthy oak tree" that has thousands of leaves "reaching to the sun" in her head but she is still a little bit confused to put it 


\section{UNIVERSITY OF CHITRAL JOURNAL OF LINGUISTICS AND LITERATURE VOL. 5 | ISSUE I | JAN - JUNE | 2021

on the paper (Anderson, 1999, p.71). In Art as Medicine, it is illustrated that the life of created image is the base of progressive and logical treatment of the "psychic diseases" of human beings (McNiff, 1992, 114). In this novel as well, the created images work as a revolutionary treatment of traumatic stress for the protagonist, Melinda Sordino. After putting imperfect and flawed trees on the paper, she starts coming out of her frustrated and depressed situation. As the growth of the tree relates to the growth of Melinda Sordino, the image of strong oak tree in the mind of Anderson's protagonist shows her own growth and transformation from a shy and little raped girl to a somewhat mature teenager who is feeling strong in her head.

At the end of the session, Melinda appears with the picture of a perfect and flourished oak tree that looks very fresh and beautiful. She illustrates that "my tree is definitely breathing" and it looks as fresh as "it just shot up through the ground this morning... Roots knob out of the ground and the crown reaches for the sun, tall and healthy" (Anderson, 1999, p.174). Melinda also paints a lower branch that is sick, but she is very hopeful that the sick branch would drop soon from this tall and vigorous tree. The sick branch of the painted tree symbolizes the bruises that are still vivid in Melinda but she is very hopeful that they will also fade with the passage of time. She has also drawn the beautiful birds sitting on the branches of the tree and some of them are flying. The projection of this tree exhibits Melinda as a resilient woman. She begins by feeling destroyed like the tree struck by lightning that she draws, but in the end feels that now she can deal with the experience of being raped, she is now free and can fly high in the sky like those painted birds who are free to fly above the painted tree. In fact, through art therapy in art class, Melinda helps herself in peeping out the window of art from her inner prison. She accepts this thing that "I have completed myself through this oak tree, I feel like I can fly...I have survived. I am here" (Anderson, 1999, p.178).

McNiff writes that on an individual level, making pictures as opposed to talking about an upsetting issue can give a proportion of control, permitting people to pick if, when, and how they will manage the implications contained in the pictures they make (McNiff, 1992, p.164). The creative art therapy also provides this measure of control to Melinda Sordino and by dealing with the meanings she put into her created images, she ultimately finds her voice and confidence and 
UNIVERSITY OF CHITRAL JOURNAL OF LINGUISTICS AND LITERATURE VOL. 5 | ISSUE I | JAN - JUNE | 2021

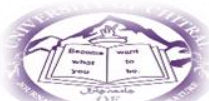

transforms into a bold girl who has the courage to speak up against her rapist. She finally talks with her ex-best friend, Rachel, about her rape for the very first time and tells her that she called the cops because a young guy raped her under the trees, and she was too drunk to know what was happening with her when he hurt her. On the last day of the year, Mr. Freeman comes to her and asks her to talk about her art. Instead of talking about her art, she simply says "let me tell you my story," the tears which come out of her eyes dissolve the "last block of ice" in her throat, and she perceives that "the frozen stillness" is melting inside her and finally she speaks up (Anderson, 1999, p.182). It becomes clear that she is going to tell the tale of her sufferings and traumatic encounters which she has faced in her adulthood including rape. Finally, she gains her voice back and raises her voice for herself. She accepts the truth that she has been raped and it is not her fault. She tells it to Rachel; she also talks about the "pain" in her art with Mr. Freeman. Even the protagonist is also determined to talk about this incident with her parents as well.

Finally, a transformed Melinda appears who is ready to speak about her rape and rapist with a clear head. She becomes a powerful girl who has the courage to resist or say no to her rapist. Andy Evans attacks Melinda once again in the closet of the school while blaming her that she is spreading the story of how he raped her. He tries to do the same thing again with Melinda which he did in the party to make her mouth shut. He pulls her away from the sight of other, puts his one hand on Melinda's mouth and the other on her throat. Melinda mentions that he put his mouth on her face, he was breathing like a "dangerous dragon" (Anderson, 1999, p. 284). His hands once again started attacking Melinda's body. But this time Melinda resists as much as she can. This time the sound that explodes from her throat is "NNNOOO!!!" (1999, p. 294). She hits the mirror in the closet twice with the wood to break it. The loud sound that explodes from Melinda and the sound of shards of glass slipping down into the sink puzzle Andy Evans. The baffled and shocked young boy pulls himself away from Melinda. She avails the opportunity, picks up a shard of glass, and "holds it to Andy Evans's neck" which makes him scared, and he surrenders while raising his hands to his heads.

This is obvious that shy, timid, and weak teenager has now become a powerful young, bold girl through her creative renderings. She completes her fragmented self through her creativity and 


\section{UNIVERSITY OF CHITRAL JOURNAL OF LINGUISTICS AND LITERATURE VOL. 5 | ISSUE I | JAN - JUNE | 2021

shows that no beast can touch her now as she has transformed into courageous girl who can raise the blood from the body of the person who would try to harm or harass her. This is the art that melts all the blockades from the path of her psychological growth. Melinda would never be able to gain such confidence and courage, if she had not stepped into the world of art with the help of his art teacher, Mr. Freeman. In the last class, she also draws the birds besides the perfect oak tree. The birds that are flying in the light and their feathers are expanding promise to Melinda. It is quite clear that this good change takes place because of the therapeutic power of art. Where the efforts of parents and guidance counselor fail, art appears as Melinda's biggest motivation as it becomes successful in transforming herself once again and in getting her open about her crucial past and the reason behind not getting good grades.

\section{Conclusion}

Through all the above discussion, the conclusion can be drawn that sexual harassment, rape, or any other traumatic encounter can ruin the victim's life badly as these traumatic experiences have physical, mental, psychological, and social consequences on the growth of the person. It is very difficult for the victims who encounter traumatic experiences to spit their anger out. However, art emerges as best spontaneous treatment for those who suffer psychologically. Anderson's character Melinda Sordino must suffer a lot in her life which pushes her into depression, anxiety, and frustration. She tries to commit suicide to escape from the hardships of life but fails. She joins art class, releases her emotions through creative renderings. After putting her suppressed emotions, she appears as transformed and powerful Melinda who has the courage and who can fight for herself. Melinda Sordino survives, gains her confidence back, and dislodges her silence through her artwork. In this way, the journey of Melinda Sordino from trauma to transcendence through creative art therapy takes place and transforms her into a bold and confident girl who is making new friends, going out to shopping malls, and not afraid of anything.

\section{References}

American Psychiatric Association. (2015). Diagnostic and Statistical Manual of Mental Disorders. Ed. 5, Washington, DC, 1-325.

Anderson, Laurie H. (1999). Speak. Penguin Publisher, USA, 1-300. 
UNIVERSITY OF CHITRAL JOURNAL OF LINGUISTICS AND LITERATURE

VOL. 5 | ISSUE I | JAN - JUNE | 2021

Arifin, Melani Nurfita. (2018). The Girl's Infliction Caused by Rape as Reflected in Laurie Halse Anderson's Speak. 1-21. [Online]

Available: https://www.semanticscholar.org/ca3b.com (December 6, 2019).

Bremner, J. Douglas. (2006). Traumatic stress: Effects on the brain. Dialogues in Clinical Neuroscience. Emerald Group Publishing Limited, 8(4), 445-461.

Cherry, Kendra. Psychotherapy: How Art Therapy is Used to Help People Heal. 1-142. [Online] Available: https:// www.verywellmind.com/what-is-art-therapy-2795755 (November 16, 2019).

Heller, Molly Anne. (2015). Becoming Incredible: Healing Trauma Through Performance. Unpublished PhD. Thesis, Utah University, Utah, 1-45.

Kristiana, K. (2012). Coping Behavior of Melinda in Speak: An Individual Psychological Approach. 1-19. [Online]

Available: https://www.eprints.ums.ac.id/19455/14/02 (January 24, 2020).

Levi, Primo. (1986). The Drowned and the Saved. Penguin Publishers, London, 1-286.

McNiff, Shaun. (1992). Art as Medicine: Creating a Therapy of the Imagination. Shambhala Publishers, USA, 1-223.

Rahma, Katrin. (2014). The Cause and Effect in Melinda's Traumatic Experiences: A Psychosocial Analysis of Anderson's Speak. 1-78. [Online]

Available: https://www.eprints.uny.ac.id/17627/pdf.com (January 17, 2020).

Richards, Marbeth Ragsdale. (2019). Caught Between Voices, Caught Between Pages. Critical Inventions in Rape Cultur. Feral Feminisms, 102-114. [Online]

Available: https://www.feralfeminisms.com/caught-between-voices/ (November 16, 2019).

Riggs, Anne. (2010). The Creative Space: The Art and Wellbeing in the Shadow of Trauma, Grief, and Loss. Unpublished PhD. Thesis, Victoria University, Australia, 1-190.

Rustiani, Novia Harry. (2008). A Study of Depression and Healing as Reflected in Anderson's Speak. 1-82. [Online]

Available: https://www.scholarcommons.used.edu/etd/143 (December 22, 2019).

Wertheim-cahen, Truus, Marion Van Dijk, and Boris Drozdek. (2004). About a Weeping Willow, a Phoenix Rising from Its Ashes and Building a House ... Art Therapy with Refugees. 
UNIVERSITY OF CHITRAL JOURNAL OF LINGUISTICS AND LITERATURE

VOL. 5 | ISSUE I | JAN - JUNE | 2021

Three Different Perspectives. Broken Spirits: The Treatment of Traumatized Asylum

Seeker Refugees, War and Torture Victims. Brunner-Routledge, USA, 419-442.

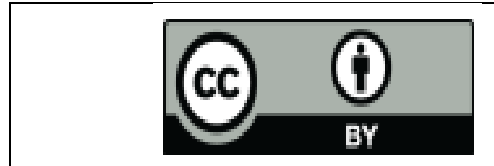

@ 2021 by the author. Licensee University of Chitral, Journal of Linguistics \& Literature, Pakistan. This article is an open access article distributed under the terms and conditions of the Creative Commons Attribution (CC BY) (http://creativecommons.org/licenses/by/4.0/). 